УДК $7.01 ; 930.85$

ББК 85.03

DOI:10.18688/aa155-4-39

Alexandra Uscatescu ${ }^{1}$

\title{
The Idea of Rome beyond Rome
}

One of the most constant features of art history is the way an art object is transmitted and transformed. So it is not surprising to observe how much late antiquity owes to Classical Roman art. The Classical art in Settis' words seems to play two roles: the basis for the development of medieval art and a privileged source from which models are extracted [48, pp. 129130]. The issue is not so simple. As I am aware of the impossibility of coping with this issue in the space available here, in the following pages, I will focus on a single element: the idea of Rome as it is materialized in the legend of Romulus and Remus. This myth was synthesized in the lupa romana image ${ }^{2}$. Augustus adopted this icon because of its very simplicity: the Augustean she-wolf denotes pietas and uirtus [54, pp. 156, 245]. This myth summarizes perfectly the idea of Rome, which survived its own destruction and was handed over to other political centres ruled by other people alien to the ancient Roman Empire. Basically, what I present here is the analysis of the appropriation of icons by certain human groups facing to dominant powers and cultures. So I will focus on the re-use of this artistic image by Anglo-Saxons, Franks, Lombards or Sogdians, between the $5^{\text {th }}$ and $9^{\text {th }}$ centuries.

\section{THE FALL OF ROME}

Paradoxically, after the fall of Rome an increasing number of panegyrists dedicated their praises to Rome, a well-known topos since Tibullus' Roma Aeterna [55], although the real Rome didn't exist any longer as an imperial city. The Aurea Roma was, however, still alive in the hearth of medieval man. Legends take up ancient beliefs and assert their values: serving as social cohesive system of a human group. No doubt, this was the way the legend of Romulus was stored in the secular memory. Against all predictions, the Primordia Vrbis survived in a Christianized Roman Empire (especially the icon of the she-wolf suckling the twins). Christian authors, namely Malalas, continue using an evemerized version of the myth ${ }^{3}$. However, this symbolic and visual iteration of Roman icon was adopted by groups culturally alienated to that tradition, which re-contextualizes the icon within their own cultural tradition ${ }^{4}$.

1 This paper is part of the results of the research project HAR2013-45578-R. Universidad Complutense de Madrid.

2 In spite of its probable medieval dating, the Lupa Capitolina bronze is excluded from this paper because it doesn't fit the Vergilian ékphrasis, since the twins were a Renaissance addition, not to mention the evidences that point to its dating to the Carolingian period [16], although the controversies about its origins (Etruscan uersus Medieval origin) still raising from the $19^{\text {th }}$ century onwards [2] [8].

Malalas, Chr. 178, 7 [37, p. 95].

Also it can be considered as a cultural re-contextualization the legend of Byzas and his half-brother Strombos and the foundation of Constantinople [12 p. 287]. 


\section{CHRISTIANIZING PAGAN SYMBOLS}

Although the Imperial Rome used the primordial icons as official symbols, its spreading made the natural appropriation of the image of the she-wolf by other people easier, even though this icon recalls romanitas by synecdoche. In addition, classical rhetoric enables Christian poets to keep the myth alive ${ }^{5}$. The late antique panegyrists evoke its picture in many ekphraseis modelled on the Virgilian Aeneas' shield ${ }^{6}$ : Sidonius Apollinaris, as well as Claudian, describe the she-wolf suckling the twins displayed on the shield of the goddess Roma ${ }^{7}$.

On the Syrian mosaic of Firkya (Ill. 65) ${ }^{8}$, the Roman she-wolf loses all her mythical potential [12, p. 328]. At least the place where it was found indicates so: a monastic hospital consecrated in December AD 511 [13, p. 34; 20; 25, p. 498; 43; 44]. It is difficult to have an idea of the concept of Rome in early Byzantine Syria, where even the name of Remus is transformed in a bizarre Roas, in a writing showing ligatures that may denote a manuscript source, as Bowersock observes [14, p. 696]. In this regard, there is an interesting contribution by Geiger on the interpretation of the legend of Romulus and Remus in the rabbinic literature, in which it becomes an example of God's mercy to the helpless [28, p. 462]. In this case, it seems that the she-wolf does not anymore represent the concept of romanitas in a $6^{\text {th }}$ century place on the periphery, despite the view of Balty [6, p. 132, note 192]. The old Roman myth preserves its whole protective potential: in $6^{\text {th }}$ century Syria, Malalas records how in his native Antioch, after the earthquake of 115, Trajan ordered an image of the she-wolf feeding the twins to be placed in the market city gate: the statue that almost worked as the talismans that Apollonius of Tyana spread throughout Constantinople, to protect the city ${ }^{9}$.

At the far end of the oikoumene, among Anglo-Saxons, the Christianization of the she-wolf seems an accomplished fact. At least its presence tangled by vine scrolls on the bone plaque of Larling (Norfolk) ${ }^{10}$ is interpreted in a similar way, a fragment of plaque that might belong to a book cover, dated to the $7^{\text {th }}-8^{\text {th }}$ centuries [29]. Its association to the Church of Saint Ethelbert in Herefordshire, the saint-king persecuted to death by king Offa of Mercia seems of no relevance, as Gannon argues [27, p. 13].

The presence of the she-wolf on the diptych of Rambona has been discussed at least since late $19^{\text {th }}$ century ${ }^{11}$. The ivory comes from the Benedictine Abbey of Saint Flavian in Macerata, a monastery built by Ageltrude, wife of Guy III of Spoleto and daughter of Adelchis, the prince of Benevento, in 898. The ivory was commissioned by Flavian, the first abbot, and was always considered as an iconographic oddity. However, the intellectual appropriation of pagan symbols are widely spread on other ivory crucifixion plaques dated to the Carolingian period, such as the Metz ivory ${ }^{12}$. In this case, the terrestrial powers are placed at the cross base [26], usually the figures of Oceanus and Tellus, personifications that could be interpreted as topographical refer-

Prudentius, Contra Sym. II, 303-304 [50, pp. 28-31].

Virgil, Aened., 8, 889-901 [24].

Sidonius Apollinaris, Paneg. Anthemius II, 395-396; Paneg. Maior. V, 21-26 [3, pp. 42-43, 62-63];

Claudian, Paneg. Probus et Olybrius, 96-99 [42].

Ma'arat an-Numa Museum, Syria.

Malalas, Chr. 235.10; and 275.14 [31, p. 125, 145-146].

Norwich Castle Museum.

Museo Sacro, Biblioteca Apostolica Vaticana, no. 62442.

London, Victoria and Albert Museum, no. 250-1867. 
ences, such as the Sun and the Moon placed above the cross denoting the crucifixion as a cosmic event. There are other formal examples that illustrate this iterance of classical patterns: the Roman sarcophagus of Villa La Pietra at Florence shows, under the imago clipeata of the decease, the she-wolf between the very same powers [23, p. 290, fig. 314-315]. Dulière interprets the shewolf occurrence on the Rambona ivory as a result of the Lombard politics equating the dominion of the medieval Rome by Lambert, son of Guy of Spoleto [23, p. 203, note 320]. Meanwhile Cracco Ruggini links the Lombard use of the she-wolf as a reaction against the Carolingian political interest on the same icon and the same city [18] [19]. But the topographical position of the she-wolf under the Golgotha has led to an alternative and simplest reading, according to which the she-wolf symbolises the ancient Rome defeated by the Redeemer's triumph, as a tamed pagan past [35, pp. 195-197]. However, I believe that the she-wolf placed in the lower register follows an ancient composition scheme (as on the Villa La Pietra's sarcophagus) and makes up the terrestrial foundation of the Church: Rome is the physical and allegorical foundation of Christianity.

\section{TELLING TALES}

The mixture of Christian narratives, classical myths and Norse legends has its greatest achievement in the famous Franks casket ${ }^{13}$, from $8^{\text {th }}$ century Northumbria. It's made of a valuable material such as whale jawbone. The juxtaposition of iconographic elements on this casket is still surprising: the recognition of Christ as Saviour Son of God and the bloody revenge of Weland, the smith, and father of the hero Widia [1, p. 550]. All the stories are placed at the same narrative level and are easily identifiable. Therefore, the Anglo-Saxon runic texts that surround the scenes, in an exotic mixture of Latin and ancient English, seem to be superfluous. According to Webster, this kind of intertextuality plays an important role, since the whole casket can be regarded as a riddle, a common practice in the Anglo-Saxon culture [52, pp. 7-8]. The she-wolf panel is accompanied by a runic text similar to the Rambona one, so the nurturing she-wolf has been interpreted as the Church feeding the Faith and offering the Salvation.

The casket's narrative organization, by means of paratactic panels, seems to reflect a common practice in Late Antiquity with many examples from the domestic realm: as the silver casket that belonged to Proiecta ${ }^{14}$, the early $5^{\text {th }}$ century Christian bride who was compared to the beautiful goddess Venus, or the Brescia ivory lipsanotheca in which the narrative scenes from the Old and the New Testament are mixed up ${ }^{15}$. In this sense, the casket's craftsman was able to translate the Christian message into a local idiom, exploiting the knowledge that the Anglo-Saxon audience has of their own cultural wealth. Much in the same way as Gregory the Great took advantage of some adapted pagan practices in order to make Christianity more attractive to the insulars [52, p. 49].

The Anglo-Saxon adaptation of Roman icons is done by addition and not by substitution: the Franks casket' scenes fit the medieval concept of Universal History, in which all the facts of the Past are part of a thread that culminates in the Salvation. It's something similar to Ernoldus Nigellus' praise of the wall painting of the Carolingian palace of Ingelheim in 825 [36, cols. 624-626]. Although these verses have been compared to the visibility of Norse skaldic

\footnotetext{
13 London, British Museum, MME 1867, 0120.1.

$14 \quad$ London, British Museum, 1866, 1229.1.

15 Brescia, Museo di Santa Giulia, Chiesa de Santa Maria in Solario.
} 
poems, they are nearer to a classical ékphrasis and directly inspired by Paulus Orosius' History [38, cols. 757-758], enlarged with the exploits of the Frankish lineage, since Ernoldus' poem illustrates Charlemagne defeating the Saxons. In this sense, this artistic development of the Universal History shows a clear Christian perspective. These palatine frescoes were arranged in opposite walls, divided between the pagan and the Christian past. Unfortunately, there is nothing in Ernoldus' description that allows us to assume that the selected foundation icon corresponds to the she-wolf and the twins.

Such a narrative mixture is also depicted on some Sogdian frescoes dated to $6^{\text {th }}-8^{\text {th }}$ centuries. Several Russians scholars have demonstrated how tales and legends of many different origins were surprisingly mixed on Sogdian wall paintings, in palaces and temples. So ancient Sogdian society revealed a long tradition in cultural appropriation, showing most of the features defined by Burke in his "Cultural Hybridity", such as frontier zone and trade vocation [15, pp. 119-120]. Marshak also pointed out that the Sogdian people used to re-contextualize alien narrative elements without giving up their own distinctive features. Central Asian painted murals visualize Aesop fables (the goose that laid golden eggs), the epic of Rostam, along with tales of Panchatantra (linked to Kalila wa Dimna). But the diffusion path seems to go in both ways: the $1^{\text {st }}$ century fables of Phaedrus or John Damascene's story of Barlaam and Josaphat derive from an early life of Buddha [7, pp. 143-147; 17, p. 303]. Not to mention Eastern decorative motives in the late antique West. On the wall painting of Qal'a-i Kahkaha palace (Shahristan, in the neighbouring Ustrushana $)^{16}$ dated to $7^{\text {th }}-8^{\text {th }}$ centuries [Ill. 66], there is a depiction of the Lupa romana that Azarpay integrates into a narrative that ends with the she-wolf icon [4, pp. 140-141, p. 202, note 66]. Marshak rightly observed that this fragmentary representation doesn't fit the Sogdian visual culture due to naked characters and others in exotic costumes [34, p. 147; 33, pp. 142-145].

A local interpretative proposal soon arose, and the she-wolf icon was promptly associated with an ancient Turkish founding myth. However, in Drompp's opinion, this myth does not have much to do with the Sogdian she-wolf painting [22, p. 518]. Though the wolf as a totem, its icon could be shared by many human groups. For example, the Chinese story of the annihilation of Tujue tribe, whose last descendant was fed by a she-wolf with whom he procreated ten human beings: the ancestors of the Turks, does not seem to fit the Sogdian wall painting nor the Bugut stele ${ }^{17}$, which seems to commemorate the establishment in AD 581 of a Buddhist community in Turkish territory, isn't at all a hypothetic representation of the Turkish primordial myth [22, p. 520].

In late antiquity, the image of the she-wolf does not necessary mean loyalty to Rome, nor its occurrence in domestic contexts could be associated with the desire of sharing the founding myth: it could be a sign of a literary culture. Even in some cases, as in the $4^{\text {th }}$ century mosaic of the horses at Carthage, it shows a playful use, as a pun or rebus to spell the name of the winner horse (Lupus, Gemellus or Romanus) [21, p. 206].

\section{TRADING AND CHARMING}

In 330, breaking with a long coinage tradition, Constantine merges two of the most relevant icons of Rome in a single currency with the personification of the city on the obverse and 
the Roman she-wolf on the back, with the two Dioscuri stars (Vrbs Roma series) [23, fig. 156] $[47, \mathrm{p} .40]$. This change in the traditional coinage by replacing the bust of emperor by the one of the Roman goddess will lead to unexpected consequences and explains the adoption of this coin type by the barbarian kings, especially the sceatta types. In addition to the coins minted by Theoderic (521-522) and his successor in Ravenna, Athalaric [23, p. 190, fig. 158], the currency of Constantine will serve as a model for the silver penny minted by Ethelbert of East Anglia. Some recent interpretations link this decision to a hypothetical homophony between the family name Wuffa and the Anglo-Saxon word for 'wolf' in its diminutive form [41, pp. 105-106; 49, p. 79], rather than a literal copy of the Roman coin, as king Ethelbert belongs to the Wuffinga dynasty that claimed to be both descendant of Caesar and symbol of romanitas [40, p. 203; 41, p. 109; 39, pp. 126-127]. However, local imitations of the Constantine coin widely circulated in other parts of Britain [27, p. 145]. Though the most curious thing of Constantine innovation was the adaptation that his coinage suffered in adjacent territories after the fall of Rome [11]: the Roman icon was decontextualized (a model extracted from a coin) and re-contextualized (in the form of bracteates, seals), and modified (with inscriptions) to fit into their new Germanic, Sogdian or Sassanian cultural environment [15, p. 133].

Accordingly, the Undley bracteate (Ill. 67) ${ }^{18}$ shows significant adaptations of the primeval icon: the goddess is masculinized by means of a beard, perhaps pointing to a heroic ethos, but its magic power seems to be reinforced by the Anglo-Frisian runic inscription that surrounds it [27, p. 146] [53]. The archaeological context in which other pieces were recovered corresponds to graves, and this fact reinforces the idea of the re-use of coins and para-monetal objects as apotropaic elements sewn to garments [27, pp. 8-9]. As for the Sogdian case, the use of bracteates is also well attested by their occurrence in the Temple II at Pendjikent ( $6^{\text {th }}$ century context) with Iranian inscriptions that would demonstrate their use as amulets [45, p. 732] [46, pp. 455-456, fig. 8,12]. As well as the small Sassanian amulet-seals that show a total dependence on Constantine's coinage, stars included. However, some variants showing zoomorphic twins could be interpreted as a local issue, following Azarpay or Gyselen, who supports an Iranian origin related to the childhood of Zoroaster or Cyrus the Great, and solves the "twins' problem" by invoking an eastern tradition of duplicate the primal unity [5, pp. 354-355; 10; 30, pp. 82-83]. According to the reading offered by Gyselen, the Pahlavi inscriptions on these amulets have invocations of demons (Duxt-Adur) or ancestors of the Sassanian dynasty (Sasan) [30, p. 57 $]^{19}$. Therefore, their magical protection power could be comparable to that of bracteates. The motivation of this Iranian cultural adaptation is a controversial issue, but in the realm of magic it seems unlikely to use "logic" in choosing motives. The belief in the power of coins and royal images is still alive in the heart of the Empire [32, p. 1040; 51, p. 106], in $4^{\text {th }}$ century Syria, where John Chrysostom claims against Christian people who bind bronze coins of Alexander the Great around their heads and feet ${ }^{20}$.

Finally, it has been stressed that it is still surprising how the Roman she-wolf icon, even after the fall of the imperial city, has been recorded all over the oikumene. This icon was used even among people beyond the ancient Roman territory. And although it is linked to roman-

\footnotetext{
$18 \quad$ London, British Museum, M\&ME 1984, 11-1.1

$19 \quad$ Gyselen's Type 7.2.

$20 \quad$ John Chrysostom, Ad Illuminandos cathechesis 2.5 [37, col. 240].
} 


\section{itas, due to its magical-protective and nurturing function it circulates among Christian com- munities as well as other Norse and Eastern ethnic groups in Late Antiquity.}

Title: The Idea of Rome beyond Rome.

Author. Alexandra Uscatescu -Ph. D., Professor. Complutense University of Madrid. Department of History of Art I (Medieval), Avenida del Profesor Aranguren s/n, 28040 Madrid, Spain. alexandra.uscatescu@ghis.ucm.es

Abstract: The weight of the Classical culture during the Middle Ages is undeniable and in this context, Roman art seems to play two opposing roles: the basis for the development of mediaeval art and a privileged source from which models are extracted. The issue is rather complex, so this argument will be supported by a single iconographic element embedded in the discourse of the idea of Rome: the she-wolf and the twins. This icon summarizing the idea of Rome survived its destruction and was adopted by other peoples alien to the Roman Empire. This paper is focused on the reception and re-use of that icon by Anglo-Saxon, Frank or Lombard peoples, between $5^{\text {th }}$ and $9^{\text {th }}$ centuries.

Keywords: Anglo-Saxons; iconography; Late Antiquity; Lombard; Lupa Romana; Romulus and Remus; Sogdian; visual culture.

Название статьи. Идея Рима после Рима.

Сведения об авторе. Ускатеску Александра - Ph. D., профессор Мадридского университета Комплутенсе, Отделение истории искусства I (кафедра Средних веков), Avenida del Profesor Aranguren s/n, Мадрид, Испания, 28040. alexandra.uscatescu@ghis.ucm.es

Аннотация. Значение античной культуры в эпоху Средневековья не подлежит сомнению. В этом контексте римское искусство играло две противоположные роли: фундаментальной основы развития средневекового искусства и первостепенного источника образцов для заимствования. Тема довольно сложная, и в подтверждение своей мысли автор обращается лишь к одному иконографическому примеру, задействованному в рассуждениях относительно идеи Рима: к образу волчицы и близнецов. Этот образ, обобщающий идею Рима, пережил его падение и был воспринят другими народами, не входившими в состав Римской империи. В статье рассматривается проблема восприятия и переработки этого образа англо-саксонскими, франкскими и ломбардскими народами в период между V и IX вв.

Ключевые слова: англосаксы; иконография; Поздняя античность; Римская волчица; Ромул и Рем; изобразительная культура.

\section{References}

1. Abels R. What has Weland to do with Christ? The Franks Casket and the Aculturation of Christianity. Speculum, 2009, no. 84.3, pp. 549-581.

2. Alföldi M. R.; Formigli E.; Fried J. Die römische wölfin. Ein antikes Monument stürzt von seinem sockel. The Lupa Romana: An Antique Monument Falls from Her Pedestal. Stuttgart, Steiner Granz Publ., 2011, 161 p.

3. Anderson W. B. (transl.). Sidonius. Poems and Letters 1-2. Loeb Classical Library. London - Cambridge, Mass Publ., Havard University Press Publ., 1936, no. 296. 483 p.

4. Azarpay G. Sogdian Painting. The Pictorial Epic in Oriental Art. Berkeley, University of California Press Publ., 1981. 212 p.

5. Azarpay G. The Roman Twins in Near Eastern Art. Iranica Antiqua, 1988, no. 23, pp. 349-360.

6. Balty J. Mosaïques Antiques du Proche-Orient. Chronologie, Iconographie, Interprétation. Paris, Les Belles-Lettres Publ., 1995. 389 p. (in French).

7. $\quad$ Ball W. Rome in the East. The Transformation of an Empire. London, Routledge Publ., 2000. 523 p.

8. Bartoloni G. (ed.). La lupa capitolina. Nuove prospettive di studio. Rome, L'Erma di Bretschneider Publ., 2010. 206 p. (in Italian).

9. Berger A. (transl.). The Patria. Accounts Medieval Constantinopolis. Dumbarton Oaks Medieval Library, vol. 24. Cambridge, Mass. - London, Harvard University Press Publ., 2013. 357 p.

10. Bivar A. A Parthian Amulet. Bulletin of the School of Oriental and African Studies, 1967, no. 30, pp. 512-525.

11. Blunt C. E. The Coinage of Offa. Anglo-Saxon Coins. London, Dolley R.H.M. Publ., 1961, pp. 39-62.

12. Bordreuil P. Gubel E. Bulletin d’antiquités archéologiques du Levant inédites ou méconnues, IV. Syria, 1987, no. 64, 3-4, pp. 309-336 (in French).

13. Bowersock G. W. Mosaics as History. The Near East from Late Antiquity to Islam. Cambridge, Mass. - London, Harvard University Press Publ., 2006. 146 p.

14. Bowersock G. W. The Rich Harvest of Near Eastern Mosaic. Journal of Roman Archaeology, 1998, no. 11, pp. $693-699$.

15. Burke P. Hibridismo cultural. Madrid, Akal Publ., 2010. 160 p. (in Spanish).

16. Carruba A. M. La Lupa Capitolina. Un bronzo medievale. Rome, De Luca editore Publ., 2006. 78 p. (in Italian).

17. Compareti M. Classical Elements in Sogdian Art: Aesop's Fables Represented in the Mural Paintings at Penjikent. Iranica Antiqua, 2012, no. 47, pp. 303-316. 
18. Cracco Ruggini L. Il dittico di Rambona (Italia). Roma e i barbari. La nascita di un nuovo mondo. Milan, Skira Publ., 2008, pp. 568-571 (in Italian).

19. Cracco Rugini L. Le diptyque de Rambona et les idées de Rome à l'époque carolingienne. Comptes rendues des séances de l’Académie des Inscriptions et Belles-Lettres, 2006, no. 150, 3, pp. 1525-1552 (in French).

20. Chaniotis A.; Corsten T.; Stroud R. S.; Tybout R. A. Apamea (Area of Firkya). Mosaic Inscriptions Commemorating a Hotel, 511 AD SEG. 37.1435 (56-1859). Supplementum Epigraphicum Graecum, 2010, no. 56, pp. 606-607.

21. Dardenay A. Les mythes fondateurs de Rome: images et politique dans l'Occident romain. Paris, Picard Publ., 2010. 237 p. (in French).

22. Drompp M. K. The Lone Wolf in Inner Asia. Journal of the American Oriental Society, 2011, no. 131, 4, pp. 515-526.

23. Dulière C. Lupa romana. Recherches d'iconographie et essai d'interpretation, 2 vols. Brussels - Rome, Institut Historique Belge de Rome Publ., 1979. 318 p. (in French).

24. Fairclough H. R. (ed.). Virgil. Aeneid: Books 7-12, Appendix Vergiliana. Loeb Classical Library, vol. 64. London Cambridge, Mass, Harvard University Press Publ., 2001. 608 p.

25. Feissel D. Inscriptions chrétiennes et byzantines. Bulletin Épigraphique, 1989, no. 102, pp. 481-509 (in French).

26. Ferber S. Crucifixion Iconography in a Group of Carolingian Ivory Plaques. Art Bulletin, 1966, no. 48, pp. 323-334.

27. Gannon A. The Iconography of Early Anglo-Saxon Coinage. Oxford, Oxford University Press Publ., 2003. 240 p.

28. Geiger J. A Christian Mosaic and a Jewish Midrash. Vigiliae Christianae, 2006, no. 60, 4, pp. 461-463.

29. Green B. An Anglo-Saxon Bone Plaque from Larling, Norfolk. Antiquities Journal, 1971, no. 51,1, pp. 321-323.

30. Gyselen R. Sceaux magiques en Iran sassanide. Studia Iranica, cahier 17. Paris, Peeters Publ., 1995.96 p. (in French).

31. Jeffreys E.; Jeffreys M.; Scott R. The Chronicle of John Malalas. A Translation. Byzantina Australiensia. Melbourne, Australian Association of Byzantine Studies Publ., 1986, no 4. 371 p.

32. Maguire H. Magic and Money in the Early Middle Age. Speculum, 1997, no. 72, 4, pp. 1037-1055.

33. Marshak B. Legends, Tales, and Fables in the Art of Sogdiana. New York, Bibliotheca Persica Publ., 2002. 187 p.

34. Marshak B.; Grenet F. Lart sogdien (IV e au IX siècles). Les arts de l'Asie central. Paris, Citadelle et Mazenod, 1999, pp. 114-163 (in French).

35. Mazzoni C. The She-Wolf: Story of a Roman Icon. Cambridge, Cambridge University Press Publ., 2010. 282 p.

36. Migne J. P. (ed.) Ermoldi Nigelli Carmen Elegiacum de Rebus Gestis Ludovici Pii. Patrologia Latina, Paris, 1864, no. 105, cols. 551-640 (in French).

37. Migne J. P. (ed.). Joannis Chrysostomi Ad Illuminandos cathechesis. Patrologia Graeca, vol. 49. Paris, 1862, cols. 223-240.

38. Migne J. P. (ed.). Pauli Orosii Historiarum aduersum paganos libri septem. Patrologia Latina, vol. 31. Paris, 1846, cols. 663-1172.

39. Moberly G. H. (ed.). Venerabilis Baedae Historia Ecclesiastica Gentis Anglorum. Oxford, Clarendon Press Publ., $1881.516 \mathrm{p}$.

40. Mommsen Th. (ed.). Historia Brittonum cum additamentis Nennii. Chronica Minora III. Monumenta Germaniae Historica, Auctores Antiquissimi. Berlin, Weidmann Publ., 1898, vol. 13, pp. 111-222.

41. Newton S. The Origins of Beowulf and the Pre-Viking Kingdom of East Anglia. Cambridge, D. S. Brewer Publ., 1994. 192 p.

42. Platnauer H. M. (ed.). Claudian II: Loeb Classical Library, 136. London - Cambridge, Mass. - Harvard University Press Publ., 1922. 432 p.

43. Pleket H. W.; Stroud R. S. Apamene. Firkia. Mosaic Inscription Commemorating a Hospital, 20 Dec. 511 AD (37-1435). Supplementum Epigraphicum Graecum, 1990, no. 37, p. 450.

44. Pleket H. W.; Stroud R. S.; Chaniotis A.; Strube J.H.M. Apamene. Firkia. Mosaic Inscription Commemorating a Hospital, 511 AD (48-1846). Supplementum Epigraphicum Graecum, 1998, no. 48, p. 604.

45. Rashke M. G. New Studies in Roman Commerce with the East. Aufstieg und Niedergang der Römischen Welt. Berlin - New York, De Gruyter Publ., 1978, vol. II, no. 2.9, pp. 604-1360.

46. Raspopova V. Gold Coins and Bracteates from Pendjikent. Coins, Art, and Chronology, Essays on the Pre-Islamic History of the Indo-Iranian Borderland. Wien, Austrian Academy of Science Publ., 1999, pp. 453-560.

47. Royo M. M. Simbología y poder en las emisiones de bronce constantinianas. Gaceta Numismática, 2008, no. 168, pp. 15-44 (in Spanish).

48. Settis S. El futuro de lo "Clásico". Madrid, Adaba Publ., 2006. 158 p. (in Spanish).

49. Ström H. Old English Personal Names in Bede’s History: an Etymological-Phonological Investigation. Lund Studies in English, vol. 8. Lund, C.W.K. Gleerup Publ., 1939. 181 p.

50. Thomson H. J. (ed.). Prudentius I. Loeb Classical Library, vol. 387. London - Cambridge, Mass Publ., Harvard University Press Publ., 1953. 401 p.

51. Trzcionka S. Magic and the Supranatural in Fourth Century Syria. London - New York, Routledge Publ., 2007. 220 p.

52. Webster L. The Franks Casket. London, British Museum Publ., 2012. 64 p.

53. West S. E. The Gold Bracteate from Undley, Suffolk. Frühmittelalterliche Studien, 1983, no. 17. p. 459.

54. Zanker P. Augusto y el poder de las imágenes. Madrid, Alianza Editorial Publ., 2008. 435 p. (in Spanish).

55. Zarini V. Histoire, panégyrique et poésie: trois éloges de Rome l'eternelle autour de l'an 400: Ammien Marcellin, Claudien, Rutilius Namatianus. Ktema, 1999, no. 24, pp. 167-179 (in French). 